DOI 10.37386/2687-0584-2021-16-206-211

УДК 069+39(908)

\title{
Е.А. Коляскина
}

Независимый исследователь, г. Бийск

\section{«Собирание» и экспонирование этнографии Бийским краеведческим музеем в 1920-е гг. ${ }^{1}$}

Аннотация. В данной статье рассматривается вопрос о начале формирования этнографических коллекций в первое десятилетие существования краеведческого музея в г. Бийске, методики полевых исследований и экспонирования. Ключевые слова: этнография, историография, музееведение, краеведение, экспонирование, Бийский краеведческий музей, народы Алтая.

16 мая 1918 г. в газете «Бийская правда» появилось объявление об организации в городе музея и просьбой «сочувствующих новому делу» передать вещи [1, с. 52]. Первоначально в фонды Бийского советского народного музея ${ }^{2}$ вошли экспонаты естественно-исторического кабинета Алтайского народного университета, а также вещи, реквизированные и принесенные «трудящимися» [2, с. 3-4; 3, с. 9, 63]. В 1920 г. были запланированы первые этнографические экспедиции «художника-архитектора» Ю. Ирасека в Чемал (13 июля -5 октября) и А. И. Аверина в ст. Усть-Чарыш (8-18 августа) [1, с. 54]. В результате первой поездки музей «обогатился 30-ю оригинальными рисунками алтайских орнаментов», были начаты «переговоры с Чемалом и находящимся в нем известным алтаеведом т. Анохиным о передаче музею целого ряда интересных рисунков и экспонатов по алтаеведению» [1, с. 57]. В том же году из с. Катанда Усть-Коксинского аймака «преподаватель-этнограф» А. Салтыков привез пояса русских старообрядцев [4, с. 56]. В 1929 г. он снова совершил этнографическую экспедицию в тот же район для сбора данных о старообрядцах Алтая и закупил для музея 10 предметов, в основном одежды старообрядцев [5]. В документальном фонде БКМ хранятся зарисовки интерьерных росписей из с. Верх-Уймон, сделанные в этой поездке [6].

В 1925 г. по заданию Бийского краеведческого музея (далее БКМ) на два месяца на Телецкое озеро и в район р. Лебедь отправился «художник-этнограф» Д. И. Кузнецов, чтобы «собрать этнографический и

\footnotetext{
${ }^{1}$ Исследование выполнено при финансовой поддержке РФФИ и Министерства образования и науки Алтайского края в рамках научного проекта № 19-49-220009 «Устная история и этнография в полевых исследованиях второй половины XX - начала XXI века как источник и метод изучения и сохранения историко-культурного наследия сельских территорий Алтайского края».

${ }^{2}$ Официальным годом открытия музея считается 1920 г.
} 


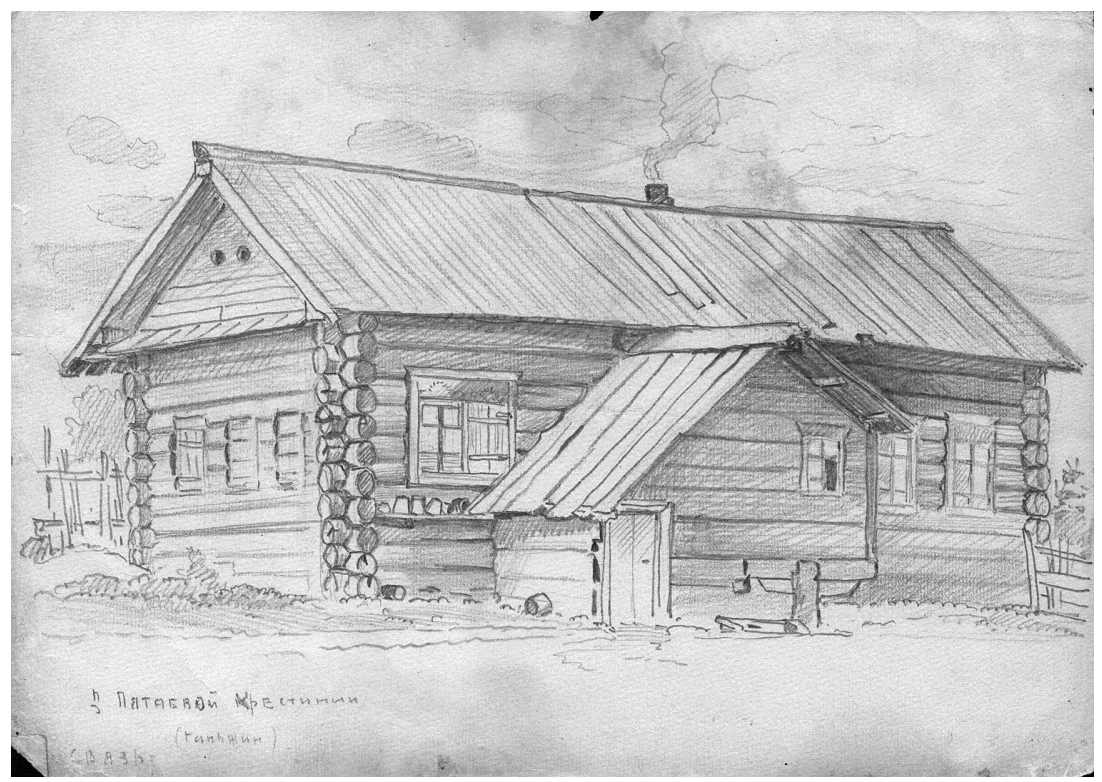

Рис. 1. Карандашный рисунок Д. И. Кузнецова. Экспедиция 1926 г. Документальный фонд БКМ.

краеведческий материал о кумандинском племени алтайцев и черневых татарах» [3, с. 79; 7]. Он входил в актив, созданный при музее из местных краеведов [2, с. 3]. С четырнадцати лет (1905) на протяжении восьми лет он каждое лето проходил обучение в мастерской алтайского художника Г. И. Гуркина в с. Анос (современный Чемальский район Республики Алтай). Там юноша общался со многими исследователями, включая А. В. Анохина, Г. Н. Потанина, Г. Д. Гребенщикова. Г. И. Гуркин заразил его «страстью к этнографическому рисунку с натуры», которые сопровождались карандашными заметками. Они совершали совместные экспедиции по Горному Алтаю [3, с. 15-22, 27].

6 июля 1926 г. Д. И. Кузнецов вновь поехал на полтора месяца в современный Турочакский район, газета «Звезда Алтая» сообщала, что в связи с необходимостью расширения экспозиции (поскольку музей получил новое двухэтажное здание) исследователь будет работать среди «туземного населения», соберет коллекции по этнографии, коллекции насекомых и сделает зарисовки [3, с. 80-81]. Из этой поездки в фонды музея поступило 87 предметов, есть рисунки кистью и карандашом, изображающие Папушкин, Сурбашкин, Санькин аилы, дома русских старожилов Алтая и их интерьеры (рис. 1) [7]. 
Следующая экспедиция Д. И. Кузнецова была организована для «сбора этнографии» среди алтай-кижи и изучения «брачного права и обряда» [7]. Газета «Звезда Алтая» от 28 августа 1928 г. писала: «Из научной командировки по Алтаю вернулся художник Кузнецов. Он собрал коллекцию насекомых, зарегистрировал 180 курганов и привез для музея богатую коллекцию этнографии. Им привезено полное оборудование и обстановка женской половины юрты: казан, архыт (кожаный мешок, в котором квасят молоко для выгонки араки), туесья и кожаные мешки с орнаментом, инструменты по выделки кож, зыбку, костюм алтайки и пр.» [1, с. 60-61]. Материал, собранный Д. И. Кузнецовым за годы работы с БКМ, содержит сведения о верованиях коренных народов Горного Алтая: деревянные божки, изображающие духов-покровителей рода, атрибуты обряда Кочокана и шаманского культа [8, с. 104].

С 1926 г., за каждым музеем Сибирского округа закреплялась территория, на которой он должен был проводить сбор и исследование материала, а также пропаганду. БКМ отводилось «верхнее течение рек Бии и Катуни и основная (горная) часть Алтая [7]. В сибирских музеях этого времени этнографические исследования считались обязательной частью культурно-исторического цикла краеведения, как и археология, история, биология, геология и т. д. [9, с. 125-129]. Это отразилось на комплексном характере экспедиций.

Развитию научно-исследовательской и собирательской деятельности сибирских музеев этого периода мешали нехватка финансирования и кадров, в БКМ в 1920-е гг. штат научных сотрудников состоял из двух человек [9, с. 131]. В газете «Звезда Алтая» за июль 1924 г. было размещено объявление о временном закрытии музея на экспедиционный период (до 1 августа), в том числе восточно-этнографического отделения [1, с. 59]. Видимо, поэтому собиратели этнографии чаще всего являлись «добровольными сотрудниками», т. е. привлекались на работу в музей только на время экспедиций, в которые они отправлялись за счет других организаций. 22 января 1928 г. газета «Звезда Алтая» писала, что Бийский музей вступил в общество по изучению производительных сил Сибири и получил от СибОНО 500 рублей на научно-исследовательские работы $[1$, с. 60]. На часть этих средств и была организована экспедиция Д. И. Кузнецова 1928 г. [7].

Нехватку сотрудников музей восполнял также за счет сети «добровольных корреспондентов», в основном из числа сельских педагогов. В документах БКМ сохранились их удостоверения; так, заведующий школой в д. Боровлянка товарищ Сары-Сэп мог собирать коллекции по всем отделам естествознания и этнологии в пределах Бащелакского и смежных с ним районов Бийского округа, учитель школы в с. Сайлап 
Т. М. Иванов - в пределах Новиковского и смежных районов. Сохранилось письмо заведующему школой с. Шумиха с просьбой приобрести для музея старообрядческие костюмы и предметы домашнего убранства, сделать зарисовку декора текстиля и жилища [7].

В первые десятилетия существования советских музеев была распространена практика обмена между ними коллекциями и литературой. На протяжении 1926-1930 гг. велась (видимо, безрезультатно) переписка Западно-Сибирского областного музея с БКМ об обмене дубликатов имеющегося и будущего «краеведческого материала по Бийскому округу и Восточному Алтаю», включая «алтайскую этнографию» на восточную коллекцию [7]. В свою очередь, после двух лет согласований состоялся обмен дубликатами коллекций между БКМ и Ойротским музеем в 1930 г. А. И. Новиков передал предметы и фотографии телеутов, алтай-кижи и казахов, собранные в Горном Алтае, совместно

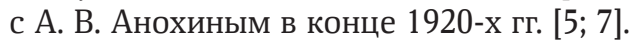

Что касается экспонирования, то в 1920 г. из-за тесноты помещения было выставлено лишь 35\% собранных вещей [2, с. 4]. Деление экспозиций на отделы было условным из-за слабой систематизации фондов. Этнографический отдел сотрудниками музея не всегда выделялся как самостоятельный. По одним данным, было открыто пять отделов: геологический, ботанический, зоологический, археологический и восточного искусства [2, с. 4]. По другим, к 1920-м гг. БКМ образовал несколько отделов, включая этнографический, но они имели «жалкий вид» $[10$, с. $60-61]$. Это было связано с тем, что в первое десятилетие существования музей четырежды переезжал и испытывал финансовые трудности. В 1923-1924 гг. экспозицию пришлось создавать заново, часть экспонатов была утеряна [2, с. 5-6]. Посетивший БКМ в 1925 г. хранитель Томского историко-археологического музея П. Славнин отмечал, что «отсутствие собственного помещения и частые переезды препятствуют плодотворной деятельности музея», в котором сформировались 9 отделов, включая этнографический [10, с. 64]. По акту обследования сотрудника Биомузея им. К. А. Тимирязева, посетившего БКМ в 1927 г., «некоторые отделы (краеведческие) в нем представлены достаточно полно: археологический, исторический и этнографический, что объясняется исключительной деловитостью работ сотрудника музея М. Д. Копытова, но и они, как и весь музей в целом, страдают бессистемностью в расположении материала, особенно две последних» [7]. В отчетных документах 1927 г. также значится этнографический отдел, но указывается, что он страдает бессистемностью [7]. Согласно отчету за 1928 г., недостаточное оборудование музея витринами способствовало хищению ценных экспонатов посетителями, раз- 
множению моли, от которой значительно пострадали экспонаты этнографического отдела; объем финансирования научной работы не позволял вести серьезные исследования, и деятельность музея сводилась к бессистемному пополнению коллекций [1, с. 61].

К 1927 г. фонд этнографии БКМ насчитывал 300 предметов; как и в большинстве сибирских музеев, они представляли преимущественно «туземцев» [9, с. 125-129]. В ноябре 1928 г. после капитального ремонта была открыта обновленная экспозиция, центром которой стали экспонаты летней экспедиции. «Советская Сибирь» писала: «Большое впечатление производят работы художника этнографа Кузнецова, собравшего и поставившего в музее алтайскую юрту со всем убранством женской половины и с манекеном алтайки из племени Алтай-кижи в ее национальном наряде, а также витрина охотника-кумандинца с принадлежностями охотничьего быта» [1, с. 61].

Таким образом, в 1920-х гг. БКМ, несмотря на финансовые, материальные и кадровые трудности, проводил достаточно активные полевые этнографические исследования, направленные преимущественно на исследование культуры коренного населения предгорий и Горного Алтая. Сложилась основа этнографического фонда, который, однако, не был систематизирован.

E. A. Kolyaskina

Independent researcher, Biysk

The Bianki Local History Museum of Biysk ethnography collection and exhibition in the 1920s.

Abstract.The article deals with the problem of the beginning of ethnographic collections in the first decade of the Bianki Local History Museum of Biysk, field research and exhibition techniques. Keywords: Ethnography, historiography, museology, local history, exhibition, the Bianki Local History Museum of Biysk, Altai peoples.

\section{Источники и литература}

1. Летопись Бийского краеведческого музея им. В. В. Бианки в документах и фактах / сост. Н. И. Занина // Бийская история Чуйского тракта. Барнаул, 2020. C. 52-128.

2. Ирисов Э., Цехановская Н. Бийскому краеведческому музею 50 лет // Краеведческий вестник. Бийск, 1970. Вып. 2. С. 3-13.

3. Прибытков Г. И. Алтайский художник-педагог Д. И. Кузнецов. Бийск, 2010.188 с.

4. Соловьева С. А. Пояса русских крестьянок (по материалам Бийского краеведческого музея им. В. В. Банки) // Краеведческий вестник. Бийск, 1999. Вып. 8. C. 56-58.

5. Отчет о деятельности музея за 1928-1932 гг. // БКМ. Документальный фонд.

6. Рисунки росписей. Этнография старообрядцев (папка) // БКМ. Документальный фонд. 
7. Отчеты Бийского краеведческого музея за 1926-1962 гг. // БКМ. Документальный фонд.

8. Соловьев С. А. Полевые экспедиции Бийского краеведческого музея им. В. В. Бианки // Краеведческий вестник. Бийск, 2014. Вып. 17. С. 103-108.

9. Ауэрбах Н. К., Черемных Г. Н. Состояние музейного дела в Сибирском крае // Жизнь Сибири. № 9-10. 1928. С. 125-134.

10. Тишкина Т. В. Музеи Алтая в первой половине 1920-х гг. // Вопросы музеологии. 2012. № 1(5). С. 59-65.

DOI 10.37386/2687-0584-2021-16-211-215

УДК 069.015

О. С. Лихачева

Алтайский государственный университет, г. Барнаул

\section{Графические реконструкции как способ популяризации древней истории (на примере выставки О. С. Лихачевой «Воскрешая прошлое Алтая»)}

Аннотация. Представленная статья посвящена теме использования графических реконструкций в популяризации древнего прошлого региона. Дается определение понятию «реконструкция», приводятся основные ее виды, отмечаются преимущества такой формы подачи материала и области ее применения. Далее рассматривается практическая реализация этого направления на примере проведения авторской выставки «Воскрешая прошлое Алтая», которая проходила в галерее «Открытое небо» в апреле 2021 г. Приводятся общие сведения о представленных на выставке работах, анализируется статистика посещаемости и возрастной состав аудитории. На основе данного опыта предлагаются дальнейшие перспективы развития данного направления. Ключевые слова: древняя история, археология, Алтай; реконструкция, графическая реконструкция, военное дело.

Под термином «реконструкция» понимается воссоздание первоначального вида объекта, явления или процесса по сохранившимся фрагментам, письменным и изобразительным источникам. По мнению исследователей, реконструкция является одной из важнейших задач археологии или даже ее главной целью [1, с. 15; 2, с. 615-616]. На сегодняшний день это направление получило наибольшее развитие в рамках военной археологии и оружиеведения в целом, что обусловлено очень яркими и репрезентативными материалами, относящимися к этой области жизни общества [3, с. 34]. Выделяется несколько видов реконструкций в зависимости от того, что является единицей информации: описательная, графическая, натуральная [1, с. 15]. Каждая из них имеет свои достоинства и недостатки и сферу наиболее рационального применения. В рамках данной статьи мы представим опыт использования графических реконструкций в области популяризации археологии. 